механізм управління економічною безпекою, який гарантуватиме, що вся діяльність підприємства є ефективною.

Таким чином, головне завдання підприємства - розробка та реалізація удосконаленої системи забезпечення та підвищення економічної безпеки підприємств залізничного транспорту. Так, з метою досягнення більшої ефективності впровадження заходів 3 підвищення рівня економічної безпеки автором пропонується цей процес розглядати в сукупності 3 процесом управління реформуванням, а саме удосконалення системи управління реформуванням галузі у напрямку орієнтації системи на цілі підвищення рівня економічної безпеки.

Перспективами подальшого дослідження $є$ деталізація та більш глибокий аналіз підходів до підвищення рівня економічної безпеки в рамках іiі конкретних функціональних складових.

\section{СПИСОК ЛІТЕРАТУРИ}

1. Васильців Т. Г. Економічна безпека підприємництва України: стратегія та механізми зміцнення : монографія / Т. Г. Васильців. - Л. : Арал, 2008. $-384 \mathrm{c}$.

2. Судакова О. I. Стратегія забезпечення належної економічної безпеки підприємства [Електронний ресурс] / О. І. Судакова, Д. В. Гречко, A.В. Шкурупій. - Режим доступу: http://www.rusnauka.com/4._SVMN_2007/Economics/1 8818.doc.htm

3. Козаченко Г. В. Экономическая

безопасность предприятия: сущность и механизм обеспечения: монография / А. В. Козаченко,
В. П. Пономарев, А. Н. Ляшенко. - К.: Либра, 2003. $280 \mathrm{c}$.

4. Білошкурська Н. В. Шляхи забезпечення економічної безпеки підприємства / Н.В. Білошкурська // MateriałyVMiędzynarodowejnaukowipraktycznejkonferencji «Dynamikanaukowychbadań 2009». 07-15 lipca 2009 roku. Volume 3. Ekonomicznenauki. - Przemyśl: Naukaistudia, 2009. C.61-63.

5. Дулеба Н.В. Визначальні фактори впливу на економічну безпеку автотранспортних підприємств/ Н.В. Дулеба // Информационные технологии в экономике, управлении и образовании. Сб. науч. тр. - СПб.: ФИНЭК, 2010.-С. 132-139.

6. Міщенко С.П. Загрози економічної безпеки залізничного транспорту в умовах реформування галузі [Електронний ресурс] / С. П. Міщенко // Матеріали IX міжнародної науковопрактичної конференції «Проблеми економіки та управління на залізничному транспорті» (ЕКУЗТ 2014) 17 листопада - 14 грудня 2014 р.. - Режим доступу: http://www.ekuzt.gov.ua/node/110

7. Маренич А.І. Виявлення та запобігання загроз кадровій безпеці / А. I. Маренич // Financialspace, 2011. - № 3 (3). - C 127 -132.

8. Матиев Д. Средства защиты информации: проблема выбора и соответствия [Електронний peсурс] / Джабраил Матиев. - Режим доступу: http://bankir.ru/publikacii/s/sredstva-zaschiti-informaciiproblema-vibora-i-sootvetstviya-5386161].

9. Печенюк А. Особливості організації інформаційної безпеки сучасного підприємства [Електронний ресурс] / А. Печенюк // Режим доступу:

http://sophus.at.ua/publ/2014_04_17_18_kampodilsk/sek cija_4_2014_04_17_18/osoblivosti_organizaciji_informa cijnoji_bezpeki_suchasnogo_pidpriemstva/54-1-0-931

УДК 005.334.2:005.934

\title{
КОРПОРАТИВНІ КОНФЛІКТИ В СИСТЕМІ ЕКОНОМІЧНОЇ БЕЗПЕКИ ПІДПРИЕМСТВА
}

\author{
Котов А. М., к.е.н., доцент, \\ Мозгова Л. О., к.е.н. (ХНЕУ ім. С. Кузнеця)
}

Визначено місие корпоративних конфліктів в системі економічної безпеки підприсмства. Проаналізовано підходи до визначення понять «економічна безпека», «конфлікт», «інтерес», корпоративний конфлікт». Представлено основні види загроз економічній безпеиі, що несе в собі корпоративне управління. Встановлено, щьо будь-який елемент ззовні $i$ всередині підприємства (акиіонерного товариства) з точки зору забезпечення безпеки може виступати одночасно в чотирьох ролях: суб'єкта забезпечення безпеки; об'єкта забезпечення безпеки; джерела загрози; об'єкта загрози.

(C) Котов А.М., 
Розглянуто типи корпоративних конфліктів залежно від учасників, проаналізовано передумови їх виникнення, представлено основні засоби їх мінімізації.

Ключові слова: загроза, інтерес, конфлікт, економічна безпека, корпоративний конфлікт, передумови, мінімізація.

\title{
КОРПОРАТИВНЫЕ КОНФЛИКТЫ В СИСТЕМЕ ЭКОНОМИЧЕСКОЙ БЕЗОПАСНОСТИ ПРЕДПРИЯТИЯ
}

\author{
Котов А. Н., к.э.н., доцент, \\ Мозговая Л.А., к.э.н. (ХНЕУим. С. Кузнеца)
}

\begin{abstract}
Определено место корпоративных конфликтов в системе экономической безопасности предприятия. Проанализированы подходы к определению понятий «экономическая безопасность», «конфликт», «интерес», корпоративный конфликт». Представлены основные виды угроз экономической безопасности, которые несет в себе корпоративное управление. Установлено, что любой элемент вне и внутри предприятия (акционерного общества) с точки зрения обеспечения безопасности может выступать одновременно в четырех ролях: субъекта обеспечения безопасности; объекта обеспечения безопасности; источника угрозы; объекта угрозы. Рассмотрены типы корпоративных конфликтов $в$ зависимости от участников, проанализированы предпосылки их возникновения, представлены основные способы их минимизачии.
\end{abstract}

Ключевые слова: угроза, интерес, конфликт, экономическая безопасность, корпоративный конфликт, предпосылки, минимизация.

\section{CORPORATE CONFLICTS IN THE SYSTEM OF ECONOMIC SECURITY}

\author{
Kotov A., PhD, Associate Professor, \\ Mozgova L., PhD (Simon Kuznets Kharkiv National University of Economics)
}

The place of corporate conflicts in the system of economic security. The approaches to the definition of "economic security", "conflict", "interest" corporate conflict. "The basic types of threats to economic security, which carries the corporate governance. Established that any element inside and outside the company (corporation) in terms of security can act simultaneously in four roles: the subject of security; facility security (protected element); sources of threat; object threat. Consider the types of corporate conflicts depending on the participants analyzed the conditions of their emergence, plant and equipment are presented minimize them. Determined that prevent corporate conflicts is reduced to improve internal and external mechanisms of corporate governance.

Keywords: threat, interest, conflict, economic security, corporate conflict, minimization.

Постановка проблеми та ї̈ зв'язки з науковими чи практичними завданнями. У сучасних умовах діяльність акціонерних товариств характеризується динамічністю i різноманіттям чинників, що впливають на неї. Ці фактори можуть сприяти як їх розвитку, так й навпаки, представляти небезпеки або загрози. Для того щоб зменшити вплив цих небезпек і загроз, необхідно створення механізмів, одним 3 яких $€$ сучасні системи економічної безпеки. Корпоративне підприємство стоїть на перехресті інтересів різних соціальних, економічних i адміністративних суб'єктів. Саме тому проблема попередження корпоративних конфліктів в системі економічної безпеки підприємства $є$ актуальною, оскільки від цього залежить результативність діяльності акціонерних товариств (АТ). Забезпечення власної безпеки актуально для всіх суб'єктів господарювання, незалежно від виду діяльності, форм власності та інших факторів. Різниця може спостерігатися лише в тому, які прийоми і методи використовує те чи інше підприємство.

Аналіз останніх досліджень $і$ публікацій. Термін «безпека» почали вживати ще в XII столітті. Він означав спокійний стан духу людини, який вважав себе захищеним від будь-якої небезпеки. Поняття «національна безпека» ввів в політичний лексикон в 1904 р. президент США Теодор Рузвельт [1]. Економічна безпека стала вперше предметом серйозних наукових досліджень в 30-ті роки в Сполучених Штатах Америки. Це було пов'язано 3 найсильнішою світовою економічною кризою і необхідністю вироблення заходів швидкого реагування на нові великомасштабні загрози. Найбільш поширеним $\epsilon$ визначення економічної безпеки підприємства як стану ефективного використання його ресурсів (капіталу, персоналу, інформації і технології, 
техніки та устаткування, прав) та існуючої ринкової можливості, що дозволяє запобігати внутрішні і зовнішні негативні впливи (загрози) i забезпечити його тривале виживання i стійкий розвиток на ринку відповідно до обраної місії. Таким чином, у розрізі економічної безпеки підприємства розглядають такі ключові поняття, як «стан корпоративних ресурсів», «стан ефективного використання ресурсів» «комплекс заходів», «захищеність діяльності підприємства», «загроза» $[2,3,4]$

Поняття «загроза» зустрічається в переважній більшості визначень поняття «економічна безпека». В даний час в літературі існує багато понять: «загроза економічній безпеці», «загроза безпеці підприємництва», «загроза безпеці підприємства» зі схожим змістом. Однією 3 таких загроз можуть бути корпоративні конфлікти.

Конфлікти є невід'ємною частиною соціально-економічного життя, що обумовлює пильну увагу вчених до дослідження природи i сутності конфліктів. Конфлікт завжди пов'язаний 3 суб' єктивним усвідомленням людьми суперечності своїх інтересів як членів тих або інших груп. Західними фахівцями конфлікти визнаються найважливішими чинниками соціального та економічного розвитку. Англійський учений М. Спенсер вважав конфлікт «неминучим явищем в історії людського суспільства і стимулом соціального розвитку» [5]. Німецький соціолог Р. Дарендорф в основу конфліктів поклав політичні чинники: боротьбу за владу, престиж, авторитет. Конфлікт, на його думку, - це наслідок соціальної нерівності. Основу соціальних конфліктів, згідно $з$ марксизмом, складає боротьба за власність [6]. Американський соціолог Л. Козер визначає конфлікт як ідеологічне явище, яке відображає устремління й почуття соціальних груп чи індивідів у боротьбі за об'єктивні цілі: владу, зміну статусу, перерозподіл доходів, переоцінку цінностей тощо [7, с. 93-95].

Корпоративне підприємство стоїть на перехресті інтересів різних соціальних, економічних і адміністративних суб'єктів. У Великому економічному словнику поняття «інтерес» визначається як «предмет зацікавленості, бажання і спонукальних мотивів дій економічних суб'єктів» [8, с. 312]. Наукове усвідомлення категорії інтересу вченими-економістами характеризується визнанням того, що інтереси - це безпосередні відносини між соціальними суб'єктами 3 приводу відтворення продукту для задоволення економічних потреб [9, с. 45]. Вчені відзначають, що економічний інтерес не психологічне явище, стан індивідуальної і суспільної свідомості, а форма необхідності реалізації матеріальних, об'єктивних потреб [10, с. 545-546].
Виділення невирішених частин загальної проблеми. Як суб'єктів інтересів економісти розглядають: людину, колективи і суспільство. Їх інтереси визначаються економічним становищем суб'єктів у суспільному виробництві. Крім цього, інтерес розглядається ними 3 метою виявлення закономірностей стимулювання та мотивації суб'єктів господарської діяльності, так як інтереси відображають матеріальні умови суспільного буття людей і формуються під безпосереднім впливом потреб. Наявність різноспрямованих інтересів спричиняе виникнення конфліктів. Якщо розглядати інтереси учасників корпоративних відносин, то мова йде про корпоративні конфлікти. У цьому секторі додаткового осмислення та вирішення потребують проблеми виникнення корпоративних конфліктів та розробки способів їх попередження та подолання в системі економічної безпеки корпорації.

Формування цілей статmі (постановка завдання). Основним завданням статті $\epsilon$ дослідження базових причин виникнення корпоративних конфліктів та визначення ключових напрямків їх попередження та подолання.

\section{Виклад} основного

матеріалу

дослідження. Акціонерні відносини $\epsilon$
найважливішим рівнем в ієрархії відносин в акціонерному товаристві i, відповідно, для економічної безпеки. У відносинах цього рівня в порівнянні 3 іншими відносинами усередині акціонерного товариства мають більшу вагу особистісні та правові аспекти. Ці відносини можна умовно розділити на наступні: відносини між власниками; відносини власники - вище керівництво; відносини власники - акціонерне товариство; відносини треті сторони (сторонні фізичні особи, юридичні особи, уповноважені органи державної влади) - власники; відносини треті сторони - акціонерне товариство. Відразу відзначимо, що всі ці відносини несуть певні протиріччя i можуть породжувати відповідні загрози.

Виходячи 3 принципу чотирьох ролей (будь-який елемент ззовні і всередині акціонерного товариства 3 точки зору забезпечення безпеки може виступати одночасно в чотирьох ролях: суб'єкта (засіб, механізм, спосіб) забезпечення безпеки; об'єкта забезпечення безпеки (захищається елемент); джерела загрози; об'єкта загрози.

Економіко-правова основа функціонування акціонерного товариства може бути використана як для забезпечення його економічної безпеки, так i для створення та реалізації загроз його економічної безпеки. Причому це стосується самого високого рівня економічної безпеки - рівня власників. 
На економічну безпеку підприємства можуть впливати такі аспекти корпоративного управління, як:

загрози проти власності (опортуністична поведінка менеджменту, ризики порушення прав акціонерів (частіше міноритарних), боротьба за корпоративний контроль, порушення права на отримання дивідендів);

інформаційні загрози (незаконне використання інсайдерської інформації, корпоративний шпіонаж, використання інформації 3 метою отримання додаткових вигод (менеджерами, акціонерами, членами наглядової ради); загрози відносин «власність - управління» (сумісництво посад в органах управління акціонерного товариства, непрямий контроль, окопування) тощо.

В табл. 1 представлено основні типи корпоративних конфліктів із визначенням передумов їх виникнення та способами мінімізації.

\section{Висновки даного дослідження.}

Забезпечення економічної безпеки господарюючого суб'єкта є складним економічним, організаційним, інформаційно-аналітичним та методичним завданням щодо створення сприятливих умов економічної діяльності господарюючого суб'єкта.

Таблиия 1

Характеристика основних типів корпоративних конфліктів

\begin{tabular}{|c|c|c|}
\hline Тип КК & Передумови & Мінімізація \\
\hline $\begin{array}{l}\text { корпорація- } \\
\text { учасники }\end{array}$ & $\begin{array}{ll}\text { виплата дивідендів } & \text { (оптимізація } \\
\text { доходів акціонерів); } & \\
\text { розвиток виробництва } & \end{array}$ & $\begin{array}{l}\text { регламентація процедури прийняття рішення про } \\
\text { виплату дивідендів, визначення умов невиплати або } \\
\text { часткової } \text { виплати дивідендів, визначення } \\
\text { мінімальної частки прибутку, рекомендованої до } \\
\text { виплати }\end{array}$ \\
\hline $\begin{array}{l}\text { учасники- } \\
\text { учасники }\end{array}$ & $\begin{array}{l}\text { проблема прийняття узгодженого } \\
\text { рішення; проблема диктатури } \\
\text { більшості } \\
\text { проблема опортунізма учасників: } \\
\text { відлунювання, } \\
\begin{array}{l}\text { встановлення } \\
\text { контролю }\end{array}\end{array}$ & $\begin{array}{l}\text { оскарження рішень у } \\
\text { кумулятивне } \\
\text { наглядової ралосування при викуп акцій, } \\
\text { меншості); } \\
\text { вказівка закону на те, що акція, оплачена не в } \\
\text { повному обсязі, не дає права голосу на загальних } \\
\text { зборах акціонерів; } \\
\text { статутом АТ можуть визначатися кількість, } \\
\text { номінальна вартість, тип акцій, що розміщується } \\
\text { додатково }\end{array}$ \\
\hline $\begin{array}{l}\text { органи } \\
\text { управління }\end{array}$ & 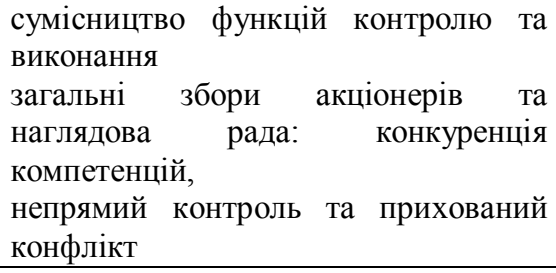 & $\begin{array}{l}\text { виключення членів виконавчого органу із складу } \\
\text { наглядової ради; } \\
\text { призначення членів виконавчого органу закріпити } \\
\text { за загальними зборами акціонерів; } \\
\text { розкриття інформації бенефіціарних власників та } \\
\text { підвищення прозорості угод }\end{array}$ \\
\hline $\begin{array}{l}\text { керуючі } \\
\text { акціонери }\end{array}$ & $\begin{array}{llll}\text { розділення } & \text { функції } & \text { власності } & \text { та } \\
\text { управління; } & & & \\
\text { окопування } & & & \\
\end{array}$ & $\begin{array}{l}\text { Система винагород, побудована на участі у } \\
\text { прибутках; } \\
\text { незалежність наглядової ради } \\
\end{array}$ \\
\hline
\end{tabular}

Звернувшись до категорії економічної діяльності, можна говорити про найважливіші умови існування господарюючого суб'єкта та забезпечення його економічної безпеки: наявність достатньої кількості необхідних ресурсів для ведення економічної діяльності; раціонально організована система управління господарюючим суб'єктом; відповідність цілей функціонування організації цілям суспільства; наявність системи ефективного захисту економічної діяльності організації від зовнішніх і внутрішніх загроз; наявність законодавчих та нормативно-правових актів i документів, що регламентують право господарюючого суб'єкта на ведення економічної діяльності тощо. Однією 3 таких умов $\epsilon$ й ефективність системи корпоративного управління, ключовою проблемою якої $\epsilon$ проблема корпоративних конфліктів, попередження яких зводиться до вдосконалення внутрішніх i зовнішніх механізмів корпоративного управління на основі запропонованих авторами напрямків.

\section{СПИСОК ЛІТЕРАТУРИ}

1. Бельков О. А. Понятийнокатегориальный аппарат концепции национальной безопасности / О. А. Бельков // Безопасность. 1994. - № 3. - C. 91 - 94.

2. Гапоненко В. Ф. Экономическая безопасность предприятий. Подходы и принципы / 
В. Ф. Гапоненко, А Л. Беспалько, А. С. Власков М.: Издательство «Ось-89», 2007. - 208 с.
3. Донцов
Г.Ю.
Экономическая

безопасность: Учебное пособие. / Г.Ю. ДонцовТомск: кафедра ТУ, ТУСУР, 2012. - 112 с.

4. Кашин А. В. Экономическая безопасность предприятия: управленческие решения : автореф. дисс.на соиск. уч. ст. к.э.н. : спец. 08.00.05 «Экономика и управление народным хазяйством (экономическая безопасность)» / А. В. Кашин. - Москва, 2008. - 27 с.

5. Спенсер Л. М. Компенции на работе / Л. М. Спенсер, С. М. Спенсер; пер. с англ. А. Яковенко. - М: НIPPO, 2005. - 384 с.
6. Дарендорф Р. Элементы теории социального конфликта / Р. Дарендорф // Социс. 1994. - № 5. - С. 142 - 147.

7. Козер Л. Функции социального конфликта / Л. Козер. - М., 2000. - 208 с.

8. Большой экономический словарь / Под ред. А.Н. Азрилияна. - М., 1999. - С. 312.

9. Интересы в системе экономических отношений социализма / Отв. редакторы: Ю. И. Палкин, Ю. Н. Пахомов. - Киев. - 1974. - 145 с.

10. Кужелев М. А. Корпоративные конфликты: сущность, виды и механизм защиты интересов собственников / М. А. Кужелев // Економіка і організація управління. - 2010. Выпуск № 1 (7). - С. 32 - 40.

Рецензент д.е.н., професор ХНЕУ ім.. С.Кузнеия Попов О.С. Експерт редакційної колегї к.е.н., дочент УкрДАЗТ Зубенко В.О.

\title{
УДК 338.242
}

\section{ПОДАТКОВА БЕЗПЕКА ЯК СКЛАДОВА ЕКОНОМІЧНОЇ БЕЗПЕКИ УКРАЇНСЬКИХ ПІДПРИЕМСТВ В УМОВАХ КРИЗИ}

\author{
Павліченко В.М., к.ю.н., ст. викладач (ХІФ УДУФМТ)
}

\begin{abstract}
В статті досліджено одну з складових економічної безпеки підприємства - податкову безпеку. Проаналізовані існуючі визначення изього поняття $i$ обрано найбільш адекватне: ие «фінансовоекономічний стан платника податків, щзо забезпечує мінімізачією податкових ризиків, при якому з боку господарюючого суб'єкта повністю й вчасно сплачуються нараховані податки, а з боку виконавчих $i$ законодавчих органів забезпечується передбачений законом захист платника податків». Також визначено місие і роль податкової безпеки в структурі економічної безпеки підприємства.

Ключові слова: економічна безпека підприємства, фінансова безпека підприємства, податкова безпека підприємства.

\section{НАЛОГОВАЯ БЕЗОПАСНОСТЬ КАК СОСТАВЛЯЮЩАЯ ЭКОНОМИЧЕСКОЙ БЕЗОПАСНОСТИ УКРАИНСКИХ ПРЕДПРИЯТИЙ В УСЛОВИЯХ КРИЗИСА}

\author{
Павличенко В.Н., к.ю.н., ст. преподаватель (ХИФ УГУФМТ)
}

\begin{abstract}
В статье исследована одна из составляющих экономической безопасности предприятия налоговая безопасность. Проанализированные существующие определения этого понятия и выбрано наиболее адекватное: это "финансово-экономическое состояние налогоплательщика, обеспечивающее минимизацию налоговых рисков, при котором со стороны хозяйствующего субъекта полностью и вовремя уплачиваются начисленные налоги, а со стороны исполнительных и законодательных органов обеспечивается предусмотренная законом защита налогоплательщика". Также определено место и роль налоговой безопасности в структуре экономической безопасности предприятия.
\end{abstract}

Ключевые слова: экономическая безопасность предприятия, финансовая безопасность предприятия, налоговая безопасность предприятия. 